\title{
PENEGAKAN HUKUM TERHADAP PELAKSANAAN PAJAK PARKIR DI KABUPATEN PELALAWAN
}

\author{
BAGIO KADARYANTO, ANDREW SHANDY UTAMA \\ Fakultas Hukum Universitas Lancang Kuning \\ e-Mail: andrew.fh.unilak@gmail.com
}

\begin{abstract}
One of the potential Regional Taxes to increase Local Revenue in Pelalawan Regency is the Parking Tax. Parking Tax is a tax on the operation of a parking space outside a body of a road, whether provided in connection with the principal of the business or that is provided as a business, including the provision of motorized vehicle day care. This research aims to explain the law enforcement of the implementation of the Parking Tax in Pelalawan Regency based on Pelalawan District Regulation Number 1 of 2011 concerning Regional Taxes. The method used in this research is socio-legal research. Parking Tax Implementation in Pelalawan Regency has not run optimally because in 2017 it is known that the Ramayana Pangkalan Kerinci and Kerinci Business Center do not deposit Parking Taxes. The efforts made by the Pelalawan Regency Financial and Asset Management Agency to maximize Local Tax revenue are forming a Regional Tax Control and Billing Task Force. Article 130 of Pelalawan District Regulation Number 1 of 2011 concerning Regional Taxes stipulates that a sanction of $400 \%$ (four hundred percent) of the principal tax payable will be imposed if any taxpayer who deliberately does not deposit the collected tax will cause losses on regional finance.
\end{abstract}

Keywords: Law, Parking Tax, Law Enforcement

\begin{abstract}
Abstrak. Salah satu Pajak Daerah yang potensial dalam menambah Pendapatan Asli Daerah di Kabupaten Pelalawan adalah Pajak Parkir. Pajak Parkir adalah pajak atas penyelenggaraan tempat parkir di luar badan jalan, baik yang disediakan berkaitan dengan pokok usaha maupun yang disediakan sebagai suatu usaha, termasuk penyediaan tempat penitipan kendaraan bermotor. Penelitian ini bertujuan untuk menjelaskan penegakan hukum terhadap pelaksanaan Pajak Parkir di Kabupaten Pelalawan berdasarkan Peraturan Daerah Kabupaten Pelalawan Nomor 1 Tahun 2011 tentang Pajak Daerah. Metode yang digunakan dalam penelitian ini yaitu penelitian hukum sosiologis. Pelaksanaan Pajak Parkir di Kabupaten Pelalawan belum berjalan optimal karena pada tahun 2017 diketahui bahwa Ramayana Pangkalan Kerinci dan Kerinci Business Center tidak menyetorkan Pajak Parkir. Adapun upaya yang dilakukan oleh Badan Pengelola Keuangan dan Aset Daerah Kabupaten Pelalawan untuk memaksimalkan penerimaan Pajak Daerah adalah membentuk Satuan Tugas Penertiban dan Penagihan Pajak Daerah. Pada Pasal 130 Peraturan Daerah Kabupaten Pelalawan Nomor 1 Tahun 2011 tentang Pajak Daerah ditegaskan bahwa akan dikenakan sanksi berupa kenaikan sebanyak $400 \%$ (empat ratus perseratus) dari pokok pajak yang terutang apabila setiap wajib pajak yang dengan sengaja tidak menyetorkan pajak yang telah dipungut sehingga menimbulkan kerugian pada keuangan daerah.
\end{abstract}

Kata kunci: Hukum, Pajak Parkir, Penegakan Hukum 


\section{A. Latar Belakang Masalah}

Pemerintahan daerah adalah penyelenggaraan urusan pemerintahan oleh Kepala Daerah dan Dewan Perwakilan Rakyat Daerah menurut asas otonomi dan tugas pembantuan dengan prinsip otonomi seluas-luasnya dalam sistem dan prinsip Negara Kesatuan Republik Indonesia sebagaimana yang dimaksud dalam UUD 1945 (Ni'matul Huda, 2012). Penyelenggaraan pemerintahan daerah diarahkan untuk mempercepat terwujudnya kesejahteraan masyarakat melalui peningkatan pelayanan, pemberdayaan, dan peran masyarakat serta peningkatan daya saing daerah dengan memperhatikan prinsip demokrasi, pemerataan, keadilan, dan kekhasan suatu daerah. Kepala Daerah sebagai penyelenggara urusan pemerintahan di daerah diberikan kewenangan oleh negara untuk mencari sumber keuangan daerah dalam bentuk Pajak Daerah dan Retribusi.

Pajak Daerah merupakan salah satu sumber utama Pendapatan Asli Daerah yang ada dalam Anggaran Pendapatan dan Belanja Daerah, yang digunakan untuk membangun daerah dan meningkatkan kesejahteraan masyarakat. Salah satu Pajak Daerah yang potensial dalam menambah Pendapatan Asli Daerah di Kabupaten Pelalawan adalah Pajak Parkir. Menurut Peraturan Daerah Kabupaten Pelalawan Nomor 1 Tahun 2011 tentang Pajak Daerah, Pajak Parkir adalah pajak atas penyelenggaraan tempat parkir di luar badan jalan, baik yang disediakan berkaitan dengan pokok usaha maupun yang disediakan sebagai suatu usaha, termasuk penyediaan tempat penitipan kendaraan bermotor.

Pada tahun 2017, Badan Pengelola Keuangan dan Aset Daerah Kabupaten Pelalawan menyegel Ramayana Pangkalan Kerinci dan Kerinci Business Center karena tidak menyetorkan Pajak Parkir, padahal tetap melakukan pemungutan Pajak Parkir kepada konsumennya.

\section{B. Metodologi Penelitian}

Penelitian hukum adalah suatu kegiatan ilmiah yang didasarkan pada metode, sistematika, dan pemikiran tertentu yang bertujuan untuk mempelajari satu atau beberapa gejala hukum tertentu dengan jalan menganalisanya (Soerjono Soekanto, 2007). Metode yang digunakan dalam penelitian ini yaitu penelitian hukum sosiologis. Penelitian hukum sosiologis adalah suatu penelitian yang dilakukan dengan cara menjelaskan pelaksanaan peraturan perundang-undangan terhadap permasalahan yang ada di masyarakat (Zainuddin Ali, 2013). Sumber data yang digunakan dalam penelitian ini adalah data primer dan data sekunder. Data primer yaitu data yang diperoleh langsung dari hasil observasi dan wawancara di lokasi penelitian. Data sekunder yaitu data yang diperoleh dari jurnal-jurnal ilmiah, literatur hukum, dan peraturan perundang-undangan. Responden dalam penelitian ini adalah Badan Pengelola Keuangan dan Aset Daerah Kabupaten Pelalawan. Teknik pengumpulan data yang digunakan dalam penelitian ini adalah observasi, wawancara, dan studi kepustakaan. Teknik analisis data yang digunakan dalam penelitian ini adalah analisis kualitatif.

\section{Hasil dan Pembahasan}

Salah satu tujuan negara adalah untuk meningkatkan kesejahteraan masyarakat. Hal ini sebagaimana yang ditegaskan dalam UUD 1945 yang menyebutkan bahwa terdapat empat tujuan dari didirikannya Indonesia sebagai sebuah negara, yaitu melindungi segenap bangsa Indonesia dan seluruh tumpah darah Indonesia, memajukan kesejahteraan umum, mencerdaskan kehidupan bangsa, serta ikut E-ISSN: 2657-0300 Lembaga Penelitian dan Penerbitan Hasil Penelitian Ensiklopedia $\quad 47$ 
melaksanakan ketertiban dunia yang berdasarkan kemerdekaan, perdamaian abadi, dan keadilan sosial (Fahrial, Andrew Shandy Utama, dan Sandra Dewi, 2019).

Pajak adalah kontribusi wajib kepada negara yang terutang oleh pribadi atau badan yang bersifat memaksa berdasarkan undang-undang dengan tidak mendapatkan imbalan secara langsung dan digunakan untuk keperluan negara bagi sebesar-besarnya kemakmuran rakyat. Salah satu fungsi pajak adalah fungsi budgetair, yaitu sumber keuangan negara (Tony Marsyahrul, 2005).

Pajak Daerah merupakan salah satu sumber utama Pendapatan Asli Daerah yang ada dalam Anggaran Pendapatan dan Belanja Daerah, yang digunakan untuk membangun daerah dan meningkatkan kesejahteraan masyarakat. Berdasarkan Pasal 1 Peraturan Daerah Kabupaten Pelalawan Nomor 1 Tahun 2011 tentang Pajak Daerah dijelaskan bahwa Pajak Daerah adalah kontribusi wajib pajak kepada daerah yang terutang oleh orang pribadi atau badan yang bersifat memaksa berdasarkan undangundang dengan tidak mendapatkan imbalan secara langsung dan digunakan untuk keperluan daerah bagi sebesar-besarnya untuk kemakmuran rakyat. Sejalan dengan itu, Tony Marsyahrul mendefinisikan Pajak Daerah adalah pajak yang dikelola oleh Pemerintah Daerah, baik Pemerintah Daerah Tingkat I maupun Pemerintah Daerah Tingkat II, dan hasilnya digunakan untuk membiayai pengeluaran rutin dan pembangunan daerah (Tony Marsyahrul, 2005).

Adapun jenis-jenis Pajak Daerah yang diatur dalam Peraturan Daerah Kabupaten Pelalawan Nomor 1 Tahun 2011 tentang Pajak Daerah yaitu Pajak Hotel, Pajak Restoran, Pajak Hiburan, Pajak Reklame, Pajak Penerangan Jalan, Pajak Mineral Bukan Logam dan Batuan, Pajak Parkir, Pajak Air Tanah, Pajak Sarang Burung Wallet, Pajak Bumi dan Bangunan Perdesaan dan Perkotaan, serta Bea Perolehan Hak atas Tanah dan Bangunan. Salah satu Pajak Daerah yang potensial dalam menambah Pendapatan Asli Daerah di Kabupaten Pelalawan adalah Pajak Parkir. Berdasarkan Peraturan Daerah Kabupaten Pelalawan Nomor 1 Tahun 2011 tentang Pajak Daerah dijelaskan bahwa Pajak Parkir adalah pajak atas penyelenggaraan tempat parkir di luar badan jalan, baik yang disediakan berkaitan dengan pokok usaha maupun yang disediakan sebagai suatu usaha, termasuk penyediaan tempat penitipan kendaraan bermotor.

Pelaksanaan Pajak Parkir di Kabupaten Pelalawan belum berjalan optimal. Pada tahun 2017, Badan Pengelola Keuangan dan Aset Daerah Kabupaten Pelalawan menyegel Ramayana Pangkalan Kerinci dan Kerinci Business Center karena tidak menyetorkan Pajak Parkir. Pajak Parkir yang harus disetorkan oleh Ramayana Pangkalan Kerinci dan Kerinci Business Center masing-masing berjumlah Rp1.500.000,- (satu juta lima ratus ribu rupiah) setiap bulannya. Akan tetapi, Ramayana Pangkalan Kerinci dan Kerinci Business Center tidak menyetorkan Pajak Parkir selama 22 (dua puluh dua) bulan. Padahal Ramayana Pangkalan Kerinci dan Kerinci Business Center tetap melakukan pemungutan Pajak Parkir kepada konsumennya.

Hambatan dalam pelaksanaan Pajak Parkir di Kabupaten Pelalawan adalah lemahnya pengawasan yang dilakukan oleh Badan Pengelola Keuangan dan Aset Daerah Kabupaten Pelalawan terhadap pengelola tempat parkir yang ada di Kabupaten Pelalawan. Hal ini dibuktikan dengan adanya pelaku usaha besar seperti Ramayana Pangkalan Kerinci dan Kerinci Business Center ternyata tidak menyetorkan Pajak Parkir selama 22 (dua puluh dua) bulan. 
Adapun upaya yang dilakukan oleh Badan Pengelola Keuangan dan Aset Daerah Kabupaten Pelalawan untuk memaksimalkan penerimaan Pajak Daerah adalah membentuk Satuan Tugas Penertiban dan Penagihan Pajak Daerah. Selain itu, Badan Pengelola Keuangan dan Aset Daerah Kabupaten Pelalawan melakukan sosialisasi kepada pelaku usaha mengenai pentingnya Pajak Parkir sebagai salah satu Pendapatan Asli Daerah yang digunakan untuk membangun daerah dan meningkatkan kesejahteraan masyarakat. Badan Pengelola Keuangan dan Aset Daerah Kabupaten Pelalawan juga mengimbau wajib pajak agar Pajak Parkir disetorkan tepat pada waktunya. Langkah terakhir yang dilakukan oleh Badan Pengelola Keuangan dan Aset Daerah Kabupaten Pelalawan terhadap wajib pajak yang tidak menyetorkan Pajak Parkir adalah melakukan penegakan hukum.

Pada tahun 2019, Badan Pengelola Keuangan dan Aset Daerah Kabupaten Pelalawan akhirnya berhasil membukukan penerimaan Pajak Parkir di Kabupaten Pelalawan mencapai $121 \%$ dari target penerimaan yang ditetapkan oleh Pemerintah Kabupaten Pelalawan. Penegakan hukum adalah upaya yang dilakukan untuk menjadikan hukum sebagai pedoman perilaku dalam setiap perbuatan hukum para subjek hukum maupun aparatur penegak hukum yang diberi tugas dan kewenangan oleh undang-undang untuk menjamin berfungsinya norma-norma hukum yang berlaku dalam kehidupan bermasyarakat dan bernegara (Andrew Shandy Utama, 2019).

Peraturan daerah dapat memuat ketentuan tentang pembebanan biaya paksaan penegakan/pelaksanaan Peraturan daerah seluruhnya atau sebagian kepada pelanggar sesuai dengan ketentuan peraturan perundang-undangan. Peraturan daerah juga dapat memuat ancaman pidana kurungan paling lama 6 (enam) bulan atau pidana denda paling banyak Rp50.000.000,- (lima puluh juta rupiah). Selain sanksi-sanksi sebagaimana dimaksud di atas, peraturan daerah dapat memuat ancaman sanksi yang bersifat mengembalikan pada keadaan semula dan sanksi administratif berupa: 1) Teguran lisan; 2) Teguran tertulis; 3) Penghentian sementara kegiatan; 4) Penghentian tetap kegiatan; 5) Pencabutan sementara izin; 6) Pencabutan tetap izin; 7) Denda administratif; dan 8) Sanksi administratif lain sesuai dengan ketentuan peraturan perundang-undangan.

Apabila ada wajib pajak yang tidak menyetorkan Pajak Parkir di Kabupaten Pelalawan, maka berdasarkan Peraturan Daerah Kabupaten Pelalawan Nomor 1 Tahun 2011 tentang Pajak Daerah dapat dikenai sanksi hukum. Pada Pasal 130 Peraturan Daerah Kabupaten Pelalawan Nomor 1 Tahun 2011 tentang Pajak Daerah ditegaskan bahwa akan dikenakan sanksi berupa kenaikan sebanyak 400\% (empat ratus perseratus) dari pokok pajak yang terutang apabila setiap wajib pajak yang dengan sengaja: a) Menolak untuk dilakukan pemeriksaan; b) Memperlihatkan pembukuan, pencatatan, atau dokumen lain yang palsu seolah-olah benar atau tidak menggambarkan keadaan yang sebenarnya; c) Tidak memperlihatkan atau tidak meminjamkan buku, catatan, atau dokumen yang menjadi dasar pembukuan atau pencatatan dan dokumen lain, termasuk hasil pengolahan data dari pembukuan yang dikelola secara elektronik atau diselenggarakan secara program aplikasi online; d) Menolak untuk dilakukan pengawasan; dan e) Tidak menyetorkan pajak yang telah dipungut sehingga menimbulkan kerugian pada keuangan daerah.

\section{Penutup}

Salah satu Pajak Daerah yang potensial dalam menambah Pendapatan Asli Daerah di Kabupaten Pelalawan adalah Pajak Parkir. Pajak Parkir adalah pajak atas penyelenggaraan tempat parkir di luar badan jalan, baik yang disediakan berkaitan E-ISSN: 2657-0300 Lembaga Penelitian dan Penerbitan Hasil Penelitian Ensiklopedia 
dengan pokok usaha maupun yang disediakan sebagai suatu usaha, termasuk penyediaan tempat penitipan kendaraan bermotor. Pelaksanaan Pajak Parkir di Kabupaten Pelalawan belum berjalan optimal karena pada tahun 2017 diketahui bahwa Ramayana Pangkalan Kerinci dan Kerinci Business Center tidak menyetorkan Pajak Parkir. Adapun upaya yang dilakukan oleh Badan Pengelola Keuangan dan Aset Daerah Kabupaten Pelalawan untuk memaksimalkan penerimaan Pajak Daerah adalah membentuk Satuan Tugas Penertiban dan Penagihan Pajak Daerah. Pada Pasal 130 Peraturan Daerah Kabupaten Pelalawan Nomor 1 Tahun 2011 tentang Pajak Daerah ditegaskan bahwa akan dikenakan sanksi berupa kenaikan sebanyak 400\% (empat ratus perseratus) dari pokok pajak yang terutang apabila setiap wajib pajak yang dengan sengaja tidak menyetorkan pajak yang telah dipungut sehingga menimbulkan kerugian pada keuangan daerah.

\section{Daftar Pustaka}

Andrew Shandy Utama. 2019. "Kepercayaan Masyarakat terhadap Penegakan Hukum di Indonesia”. Jurnal Ensiklopedia Social Review, Vol. 1 No. 3, Hal. 306-313.

Fahrial, Andrew Shandy Utama, dan Sandra Dewi. 2019. "Pemanfaatan Corporate Social Responsibility (CSR) terhadap Pembangunan Perekonomian Desa". Jurnal Wawasan Yuridika, Vol. 3 No. 2. Hal. 259-272.

Ni'matul Huda. 2012. Hukum Pemerintahan Daerah. Bandung: Nusa Media.

Peraturan Daerah Kabupaten Pelalawan Nomor 1 Tahun 2011 tentang Pajak Daerah.

Siswanto Sunarno. 2012. Hukum Pemerintahan Daerah di Indonesia. Jakarta: Sinar Grafika.

Soerjono Soekanto. 2007. Pengantar Penelitian Hukum. Jakarta: UI Press.

Soerjono Seokanto. 2013. Faktor-faktor yang Mempengaruhi Penegakan Hukum. Jakarta: Rajawali Pers.

Tony Marsyahrul. 2005. Pengantar Perpajakan. Jakarta: Grasindo.

Undang-Undang Republik Indonesia Nomor 23 Tahun 2014 tentang Pemerintahan Daerah.

Zainuddin Ali. 2013. Metode Penelitian Hukum. Jakarta: Sinar Grafika. 